\title{
HUBUNGAN ANTARA PEMBANGUNAN BERKELANJUTAN DENGAN COMMUNITY BASED TOURISM: A SYSTEMATIC LITERATURE REVIEW
}

\author{
Miranda Rista Ilhami ${ }^{*}$, Salahudin ${ }^{2}$ \\ 1,2 Program Studi Ilmu Pemerintahan, Universitas Muhammadiyah Malang \\ *)Korespondensi: mirandaristailhami@gmail.com
}

\begin{abstract}
Abstrak
This study aims to examine more deeply the relationship between sustainable development and community based tourism. This study uses a systematic literature review method, articles taken from publications of various publishers, using the SCOPUS database and given a limitation on the year of publication from 2019 to 2021. The results of this study indicate that CBT is one of the most important approaches in realizing sustainable development. CBT has a very close relationship with sustainable development, where $C B T$ is considered a very effective strategy to realize sustainable development, because $C B T$ focuses on local communities where local communities play an active role as resource owners as well as main actors in the development of their natural resources.In this CBT concept, the community is empowered to develop their skills, culture, and natural potential without destroying it in the slightest, because one indicator of the success of sustainable development is environmental conservation. The limitation of this research is that the researcher only focuses on the relationship between sustainable development and CBT and has not discussed the relationship of sustainable development with other indicators and in this study the researcher only used a limited number of previous studies, which were only 266 articles. So suggestions for further researchers who are interested in researching sustainable development are to examine the relationship of sustainable development with other indicators and can use more previous research so that it can be generalized in a wider discussion.
\end{abstract}

Article Histori:

Accepted: 18/7/2021

Review: 4/10/2021

Publish: 31/10/2021

Keyword: Sustainable Development, Community Based Tourism, Local Communities, Systematic Literature Review

\section{PENDAHULUAN}

Sektor pariwisata sebagai salah satu sektor ekonomi harus memainkan peran penting dalam mewujudkan pembangunan berkelanjutan (Abuhay et al., 2019). Sektor pariwisata diistilahkan sebagai agen perubahan budaya yang berpengaruh pada seseorang, adat istiadat, serta cara berfikir masyarakat. Maka dari itu dalam meningkatkan arus gelombang wisata harus memiliki perencanaan yang matang, karena jika meningkatkan gelombang wisata tetapi tidak sinergis dengan perencanaan yang matang dikhawatikan akan berdampak negatif terhadap kondisi sosial budaya masyarakat. Salah satu faktor penentu bahwa pariwisata dapat berdampak positif pada lokalitas yaitu penerapan model pengembangan pariwisata yang tepat, community based tourism dinilai salah satu model pengembangan pariwisata yang cocok dengan pembangunan pariwisata lokal karena community based tourism berfokus pada sumber daya dan manfaat lokal (Giampiccoli \& Mtapuri, 2020).

Community Based Tourism merupakan salah satu pendekatan terpenting dalam 
mewujudkan pembangunan berkelanjutan. Community Based Tourism didorong sebagai salah satu strategi pengentasan kemiskinan serta dapat meningkatkan keberlanjutan daerah dan masyarakat yang terpinggirkan, persepsi yang menguntungkan terhadap CBT yaitu CBT dinilai sebagai alat yang dapat berkontribusi pada keberlanjutan lingkungan sosial ekonomi dan fisik di wilayah pedesaan (Juma \& KhademiVidra, 2019). Community Based Tourism merupakan pendekatan yang dapat digunakan sebagai strategi yang saling menguntungkan untuk pembangunan lokal yang berkelanjutan dan melestarikan keanekaragaman hayati (Sène-Harper \& Séye, 2019). Produk dari pariwisata berbasis masyarakat berpotensi untuk diunggulkan sebagai produk baru untuk menarik minat wisatawan lokal maupun wisatawan mancanegara dalam mengetahui manfaat produk berbasis komunitas di pedesaan (Rami et al., 2019). Community Based Tourism dinilai sebagai pariwisata yang berkelanjutan dan dapat membantu masyarakat pedesaan untuk meningkatkan taraf hidup mereka tanpa merusak lingkungan melainkan mengembangkan potensi alam pedesaan yang mereka miliki.

Dalam penerapan konsep community based tourism ini masyarakat memiliki peran sangat penting dalam pengembangan pariwisata. Masyarakat harus berpartisipasi aktif dalam proses pengembangan pariwisata mulai dari perencanaan; pembangunan; pengelolaan; pengembangan; pemantauan; serta evaluasi karena salah satu tujuan dari diterapkannya CBT yaitu untuk meningkatkan kesejahteraan dan kualitas hidup masyarakat. CBT dapat digunakan sebagai strategi untuk mengurangi kemiskinan di masyarakat lokal sekaligus mempromosikan potensi alam, budaya, dan keterampilan yang mereka miliki. CBT yang direncanakan dengan baik diyakini mampu meningkatkan peran serta masyarakat lokal dalam pengembangan pariwisata. Sekaligus memperoleh manfaat sosioekonomi yang bermakna dan berkelanjutan. Atas dasar peran serta masyarakat, hal itu juga dapat mempromosikan potensi alam yang dimiliki (Hlengwa \& Maruta, 2019).

Community Based Tourism dinilai sebagai strategi yang sangat efektif untuk mewujudkan pembangunan berkelanjutan, karena CBT berfokus pada masyarakat lokal yang dimana masyarakat lokal berperan aktif sebagai pemilik sumber daya sekaligus aktor utama dalam pengembangan sumber daya alam yang dimiliki. Jadi di dalam konsep Community Based Tourism ini, masyarakat diberdayakan untuk mengembangan keterampilan, budaya, serta potensi alam yang mereka miliki tanpa merusaknya sedikitpun, karena salah satu indikator keberhasilan pembangunan berkelanjutan adalah pelestarian lingkungan. CBT juga menjadi strategi dalam meningkatkan keberlanjutan destinasi wisata yang berlandaskan pada konsep ekonomi kreatif. Selain itu, CBT juga dapat dijadikan sebagai peningkatan pariwisata yang layak untuk kegiatan ekonomi di daerah pedesaan dan meningkatkan taraf hidup masyarakat pedesaan, serta CBT juga dapat dijadikan sebagai strategi untuk memahami implikasi pembangunan pariwisata dari sudut pandang masyarakat untuk membantu meningkatkan pengetahuan faktor-faktor yang mempengaruhi keberhasilan destinasi pariwisata dalam jangka panjang dan berkelanjutan (Muresan et al., 2019).

Dari beberapa pemaparan poin-poin penting diatas dapat disimpulkan bahwa penelitian ini mengkaji tentang hubungan antara pembangunan berkelanjutan dengan community based tourism. Alasan peneliti tertarik membahas topik ini karena CBT merupakan salah satu 
pendekatan pariwisata yang dianggap dapat mencapai kemajuan Sustainable Development Goals (SDG's) pertama yaitu tanpa kemiskinan dan Sustainable Development Goals ke sebelas yaitu kota dan komunikasi berkelanjutan yang dimana SDG's tersebut harus tercapai di tahun 2030.

Perbedaan penelitian ini dengan penelitian terdahulu lainnya yaitu terkait dengan fokus kajian. Dalam penelitianpenelitian terdahulu, banyak peneliti yang lebih fokus ke strategi pembangunan berkelanjutan dan penerapan community based tourism, sedangkan dalam penelitian ini lebih fokus mengkaii lebih dalam terkait hubungan antara pembangunan berkelanjutan dengan community based tourism. Berdasarkan beberapan urgensi terkait pembangunan berkelanjutan dan community based tourism yang telah dijelaskan oleh penelitianpenelitian terdahulu, peneliti melihat masih terbatas uraian komprehensif mengenai hubungan antara pembangunan berkelanjutan dengan community based tourism. Sehingga dalam penelitian ini, peneliti berusaha mengisi kekosongan tersebut dengan menggunakan pendekatan systematic literature review.

Penelitian ini bertujuan untuk berkontribusi dalam memberikan uraian yang lebih jelas mengenai hubungan antara pembangunan berkelanjutan dengan community based tourism. Penelitian ini berusaha mengkonstruksikan strategi pembangunan berkelanjutan dan penerapan CBT dalam pengembangan pariwisata berdasarkan literatur yang telah ada.

\section{KAJIAN LITERATUR}

Dalam penelitian ini, peneliti menggunakan systematic literature review. Systematic literature review ini sangat penting dilakukan, karena dengan melakukan systematic literature review peneliti dapat mengetahui dan mengkaji lebih dalam terkait isi dari sebuah paper yang berkaitan dengan tema kajian penelitian ini, serta dengan systematic literature review peneliti akan menambah wawasan dan dapat menempatkan diri sebagai "state of the art" atau perkembangan terkini dalam bidang yang bersangkutan. Tujuan peneliti melakukan systematic literature review yaitu untuk memahami isi dari sebuah paper dengan mencari dan menggali lebih dalam poin penting yang terdapat dalam paper tersebut dan apa yang diargumentasikan oleh penulis paper tersebut. Selain itu systematic literature review memiliki tujuan untuk memberikan pemahaman yang lebih luas kepada para penulis artikel tentang sebuah topik yang akan diteliti, sehingga dapat membantu peneliti dalam memahami beberapa topik kajian tanpa membaca seluruh isi dari paper atau jurnal. Systematic literature review memberikan banyak manfaat untuk seorang peneliti atau penulis yaitu memperdalam pengetahuan tentang bidang atau topik yang ada diteliti; mengetahui hasil penelitian dari beberapa penelitian terdahulu yang berkaitan dengan topik kajian yang akan dibahas; mengetahui perkembangan ilmu pada bidang yang akan dikaji; memperjelas masalah penelitian; serta mengetahui metode-metode yang diusulkan para peneliti untuk menyelesaikan masalah penelitian.

Dalam penelitiannya Radianto et al. (2019) menjelaskan bahwa Pembangunan pariwisata sangat erat kaitannya dengan pertumbuhan ekonomi, baik dalam jangka pendek maupun jangka panjang. Pariwisata tidak hanya memberikan kontribusi sosial ekonomi, tetapi juga menciptakan platform yang harmonis bagi semua kalangan masyarakat untuk bertukar, berbagi, dan memahami satu sama lain dengan lebih baik untuk mendapatkan kerjasama, rasa memiliki, dan imtegritas (Mohanty et al., 2019). Pembangunan pariwisata dinilai 
dapat menghasilkan eksternalitas positif terhadap kesejahteraan mayarakat, serta adanya pengembangan pariwisata dapat dimasukkan ke dalam agenda pembangunan berkelanjutan yang lebih luas (Yergeau, 2020). Dalam pengembangannya, pariwisata harus bersifat pembangunan yang bermanfaat bagi masyarakat lokal dengan meningkatkan kualitas hodup dan standar hidup masyarakat setempat dan perdagangan lokal (Strydom et al., 2019).

Pariwisata memiliki peran yang penting dalam perencanaan pembangunan berkelanjutan serta penentu dalam mewujudkan keberhasilan destinasi jangka panjang. Dalam penelitiannya Santos et al. (2020) menjelaskan bahwa pentingnya memahami citra dan persepsi wisatawan tentang suatu destinasi untuk perencanaan pariwisata karena destinasi memainkan peran kunci dalam keputusan wisatawan. Dalam pariwisata perlu mempertimbangkan dua konsep kunci yaitu persepsi dan berkelanjutan. Hasil penelitiannya Santos et al. (2020) mengungkapkan bahwa persepsi keberlanjutan dalam pembangunan pariwisata berkelanjutan berfokus pada persepsi wisatawan, pemangku kepentingan, dan penduduk. Temuan ini menyoroti perlu adanya keterlibatan masyarakat lokal dalam proses perencanaan destinasi untuk menyelaraskan hasil pengembangan pariwisata dengan harapan masyarakat. Dalam penelitian Chan et al. (2021) menyimpulkan bahwa penguatan ketangguhan destinasi harus dicapai melalui kolaborasi yang efektif antara pemangku kepentingan lokal termasuk sektor publik, sektor swasta, dan organisasi non-pemerintahan atau berbasis masyarakat lainnya.

Perencanaan pariwisata modern suatu destinasi harus melibatkan partisipasi dari semua tingkatan masyarakat seperti pemangku kepntingan, masyarakat lokal, dan kelompok umur yang bereda jika proses partisipatif ingin luas dan universal dalam masyaraka, Perencanaan partisipatif sebagai faktor penentu keberhasilan dalam upaya memenuhi persyaratan paradigma modern tentang keberkanjutan dan tanggung jawab dalam pariwisata (Koščak et al., 2019). Keterlibatan masyarakat dalam proses perencanaan pembangunan dan pengembangan jenis pariwisata menghasilkan manfaat sosial dan ekonomi yang nyata bagi masyarakat lokal. Hasil penting dari perencanaan partisipatif adalah proses pembelajaran kolektif yang berlangsung melalui proses dialog yang mendasarinya. Dalam penelitian Koščak et al. (2019) berfokus secara rinci pada peran anak-anak dan remaja dalam proses partisipatif dalam mengembangkan pariwisata berkelanjutan di tingkat lokal. Hal tersebut termasuk pandangan bahwa perencanaan pembangunan pariwisata berkelanjutan merupakan upaya membentuk masa depan. Diantara pembangku kepentingan dan peserta masyarakat, anak-anak dan remaja memiliki suara yang signifikan di masa depan dan harus memiliki hak untuk terlibat dalam pembangunan dan perencanaan pengelolaan destinasi lokal.

Dalam penelitiannya Ibrahim et al. (2019) menjelaskan bahwa pengembangan pariwisata lokal dapat meningkatkan kesejahteraan masyarakat, masyarakat setempat ditemukan telah meningkatkan tingkat sosial ekonomi mereka melalui kesempatan kerja; pendapatan tambahan dan keterampilan bahasa. Hasil penelitian dari Nordin et al. (2020) menyatakan bahwa Pembangunan pariwisata lebih banyak memiliki dampak positif dari pada dampak negatif, adanya pembangunan pariwisata ini dinilai dapat meningkatkan kualitas hidup masyarakat. Dalam penelitiannya Nordin et al. (2020) juga menemukan pengaruh manfaat sosial 
budaya, manfaat ekonomi, biaya ekonomi, dan manfaat lingkungan memiliki hubungan yang signifikan dengan kualitas hidup, adanya temuan ini sangat penting bagi perencanaan dan pengembangan dalam merencanakan pembangunan pariwisata yang strategis dan berkelanjutan di destinasi pariwisata. Meski memiliki banyak dampak positif, pariwisata lokal ini juga memiliki tantangan, oleh karena itu sangat penting untuk memahami sejauh mana kesejahteraan masyarakat di tengah pembangunan pariwisata yang merupakan elemen kunci dalam mewujudkan masyarakat yang berkelanjutan (Ibrahim et al., 2019).

Wisata pedesaan merupakan salah satu jenis pariwisata yang memiliki banyak manfaat potensial termasuk lapangan pekerjaan, basis ekonomi yang diperluas, pembangunan sosial, kesejahteraan masyarakat, dan kebangkitan kerajinan lokal (Nicolaides, 2020). Dalam pengembangan pariwisata pedesaan modern, perlu menggali lebih dalam tentang budaya pedesaan yang khas dan terus meningkatkan daya tarik wisata pedesaan (Fan, 2020). Pengembangan ekowisata di daerah pedesaan tidak hanya membantu mengembangkan modernisasi pedesaan, tetapi juga meningkatkan pembangunan peradaban spiritual antara daerah perkotaan dan pedesaan secara komprehensif serta mempersempit kesenjangan antara daerah perkotaan dan pedesaan (Fan, 2020).

Wisata pedesaan sangat erat kaitannya dengan pariwisata budaya dan ekowisata. Pariwisata budaya, ekowisata dan pembangunan pariwisata berkelanjutan berpengaruh positif dan signifikan terhadap daya saing destinasi, ekowisata secara langsung tidak berpengaruh signifikan terhadap daya saing destinasi, tetapi ekowisata secara tidak langsung berpengaruh signifikan terhadap daya saing melalui pengembangan pariwisata berkelanjutan (Roziqin \& Syarafina, 2021;
Wardana et al., 2019). Pariwisata berkelanjutan menjadi salah satu industri yang mampu mendorong pembanguann berkelanjutan (sustainable development) karena hubungannya berkaitan dengan semua aspek destinasi, mulai dari transportasi dan budaya hingga pengelolaan sumber daya alam (Feyers et al., 2020). Dalam mewujudkan pariwisata dan pembangunan berkelanjutan dibutuhkan partisipasi mayarakat. Adanya partispasi masyarakat akan menghasilkan keputusan perencanaan dan rancangan berdasarkan kebutuhan dan prioritas masyarakat guna menghasilkan rancangan, rencana, dan program yang lebih baik (Wikantiyoso et al., 2021).

Dalam penerapannya, wisata pedesaan menghadapi dua tantangan, yaitu tantangan internal dan eksternal. Tantangan terbesar dalam konteks maju dan berkembang muncul dari masalah yang terkait dengan sumber daya internal, sedangkan tantangan eksternal muncul dalam konteks memajukan suatu destinasi pedesaan (Rosalina et al., 2021). Dalam mempromosikan wisata pedesaan tradisional perlu adanya kekuatan komunitas, selain itu perlu peningkatan kapasitas internal pedesaan dan peluang untuk strategi pembangunan yang lebih inklusif untuk pelestraian wisata pedesaan di masa depan; pembuatan kebijakan; serta pengembangan pariwisata pedesaan (Jia et al., 2020).

Berdasarkan hasil penelitian Saarinen et al. (2020) menyatakan bahwa dalam pembangunan pariwisata terdapat minimnya manfaat dan partisipasi lokal dalam pariwisata yang membatasi potensi pariwisata untuk dikembangkan demi terwujudnya pembangunan lokal yang berkelanjutan. Dalam meningkatkan partisipasi masyarakat, kekuatan komunitas sangat diperlukan, karena dengan komunitas dapat memberdayakan 
masyarakat dengan mengalihkan fokus ke paradigma yang dimulai dari dalam masyarakat lokal itu sendiri (Nguyen et al., 2021). Selain itu, komunitas juga digunakan untuk memungkinkan masyarakat mencapai apa yang mereka inginkan (Nguyen et al., 2021). Dalam penelitiannya Wondirad \& Ewnetu (2019) di Dinsho (Ethiopia), partisipasi masyarakat yang ada sesuai dengan kontinum non-partisipasi dimana warga Negara hanya tertipu oleh partsipasi palsu dan tokenistik yang menyebabkan pembagian keuntungan tidak adil. Dari hasil penelitian tersebut dapat dilihat bahwa keterlibatan komunitas dalam pengembangan pariwisata sangat bergantung pada sifat pemangku kebijakan dan latar belakang ekonomi komunitas (Wondirad \& Ewnetu, 2019).

Menurut McNaughton et al. (2020) pendekatan kerangka kerja partisipatif yang berpusat pada masyarakat dapat membantu memberdayakan masyarakat dalam pariwisata dengan menyediakan visibilitas yang lebih baik dan penyampaian layanan yang ditingkatkan untuk operator kecil. Hasil penelitian McNaughton et al. (2020) juga menjelaskan bahwa pentingnya kontribusi masyarakat dalam meningkatkan pembangunan dan kapasitas yang inklusif dan berkelanjutan. Selain itu, secara khusus juga dijelaskan bahwa pemuda diberikan pelatihan untuk membuat dan memelihara infrastuktur digital (pemetaan komunitas), memberikan kemampuan lokal yang penting dan dapat digunakan kembali untuk jenis kegiatan pengumpulan data berbasis lapangan lainnya sehingga dapat memberikan peluang ekonomi alternatif, data yang didapatkan kemudian dijadikan sebagai tambahan pengetahuan lokal untuk menetapkan apa yang seharusnya ditawarkan oleh masyarakat dalam pengembangan pariwisata.
Salah satu faktor penentu bahwa pariwisata dapat berdampak positif pada masyarakat lokal yaitu penerapan konsep pengembangan pariwisata yang sesuai dengan potensi alam yang dimiliki, community based tourism dinilai salah satu model pengembangan pariwisata yang cocok dengan pembangunan pariwisata lokal karena community based tourism berfokus pada sumber daya, pemberdayaan masyarakat dan manfaat lokal. Pendekatan community based tourism merupakan salah satu prasyarat untuk pengembangan pariwisata berkelanjutan. Community Based Tourism telah muncul sebagai cara untuk memastikan bahwa masyarakat akan mendapatkan keuntungan dari industri pariwisata (Strydom et al., 2019). CBT secara luas dianggap sebagai cara yang efektif untuk mempromosikan pembangunan dan melestarikan sumber daya alam, CBT memiliki potensi untuk mendorong pengelolaan jangka panjang dan transformasi kesadaran ekologis di antara masyarakat pedesaan (Raftopoulos, 2020). Community based tourism telah menjadi pendekatan pengembangan pariwisata yang semakin disukai banyak masyarakat, karena penerapan community based tourism ini membuka peluang yang lebih inklusif untuk memberdayakan masyarakat sesuai dengan gagasan yang tercermin dalam tujuan pembangunan berkelanjutan (SDGs) (Dolezal \& Novelli, 2020).

Dalam penerapannya, community based tourism ini diperlukan adanya partipasi aktif dari masyarakart, masyarakat dapat bertindak sebagai agen perubahan untuk mewujudkan tujuan ekowisata dan pembangunan berkelanjutan (D'Souza et al., 2019). Hasil penelitian dari Pranee, (2019) menunjukkan bahwa pengelolaan wisata dalam konsep community based tourism tidak terlepas dari sinergi masyarakat untuk merefleksikan ide-ide 
kreatif mereka dan mengembangkan sumber daya yang mereka miliki serta untuk meningkatkan lapangan pekerjaan dan berkontribusi pada peningkatan pendapatan masyarakat setenpat. Dalam studi pariwisata, CBT sering diasumsikan sebagai solusi mengatasi ketidakseimbangan daya dengan melibatkan semua pemangku kepentingan dalam proses memenuhi keinginan semua pemangku kepentingan, selain itu pemberdayaan masyarakat lokal dengan model CBT tidak terlihat hanya secara ekonomi, melainkan juga dalam dimensi lain (Cornelisse, 2020).

Hasil penelitian Stone \& Stone, (2020) menunjukkan bahwa konsep community based tourism di Botswan dapat dirunut pada dimulainya Pengelolaan Sumber Daya Alam Berbasis Masyarakat yang memiliki keberhasilan dan tantangan. Temuan dalam penelitian Stone ini menunjukkan bahwa pengembangan community based tourism memiliki tantangan yaitu masalah komunitas, partisipasi multi-pemangku kepentingan, keragaman dan heterogenitas, kekurangan dalam ketajaman bisnis, kurangnya rencana distribusi pendapatan dan prioritas investasi kembali dan partisipasi pasif masyarakat. Melihat tantangan-tantangan tersebut, di masa depan mungkin lebih sulit untuk mewujudkan community based tourism yang berkelanjutan.

Community Based Tourism (CBT) cocok diterapkan dan dikembangkan di Negara-negara berkembang, karena community based tourism ini dinilai dapat digunakan sebagai upaya pengentasan kemiskinan (Müllera et al., 2020). Community Based Tourism merupakan salah satu model pengembangan pariwisata yang berpotensi meningkatkan pertumbuhan sosial ekonomi masyarakat, keterampilan bahasa, serta warisan budaya (Nomnian et al., 2020). Dalam penelitian Pickel-Chevalier et al. (2019) menunjukkan bahwa ketiga desa yang ada di Bali berhasil memenuhi ekspetasi pariwisata berkelanjutan dengan mendukung pertumbuhan ekonomi yang memungkinkan masyarakat lokal untuk menjaga komunitas masyarakat tetap hidup melalui community based tourism yang menghormati organisasi tradsional secara global. CBT ini merupakan bentuk baru dari pariwisata berkelanjutan yang memiliki berbagai keuntungan finansial maupun non finansial bagi masyarakat lokal serta memaksimal pembangunan keberlanjutan di tingkat lokal (Han et al., 2019). CBT merupakan salah satu pendekatan pariwisata yang dianggap dapat mencapai kemajuan Sustainable Development Goals pertama yaitu tanpa kemiskinan dan Sustainable Development Goals ke sebelas yaitu kota dan komunikasi berkelanjutan (Pasanchay \& Schott, 2021).

\section{METODE PENELITIAN}

Penelitian ini bertujuan untuk mengkaji berbagai artikel ilmiah yang membahas terkait pembangunan berkelanjutan dan community based tourism yang telah dipublikasikan di jurnal internasional berputasi. Selain itu, review dalam kajian ini diarahkan pada konseptualisasi kajian hubungan antara pembangunan berkelanjutan dengan Community Based Tourism yang akan dijelaskan melalui pertanyaan-pertanyaan berikut, yaitu: (1) Bagaimana hubungan dan klasterisasi tema dalam kajian hubungan antara pembangunan berkelanjutan dengan community based tourism? (2) Apa saja tema dominan dalam kajian hubungan antara pembangunan berkelanjutan dengan community based tourism? (3) Apa saja topik yang berkaitan dengan kajian hubungan anatara pembangunan berkelanjutan dengan 
community based tourism? (4) Jenis pemetaan apa yang digunakan dalam studi hubungan antara pembangunan berkelanjutan dengan community based tourism? (5) Konsep apa yang digunakan dalam kajian hubungan antara pembangunan berkelanjutan dengan community based tourism?. Dari beberapa pertanyaanpertanyaan tersebut akan dijelaskan berdasarkan dengan topik kajian, kerangka kerja, dan beberapa temuan penelitian terdahulu yang telah terindesk dalam database Scopus. Artikel yang akan direview dalam penelitian ini akan melalui beberapa tahapan yaitu (1) pencarian artikel; dan (2) pemetaan topik.

Bagan 1. Proses Review Artikel

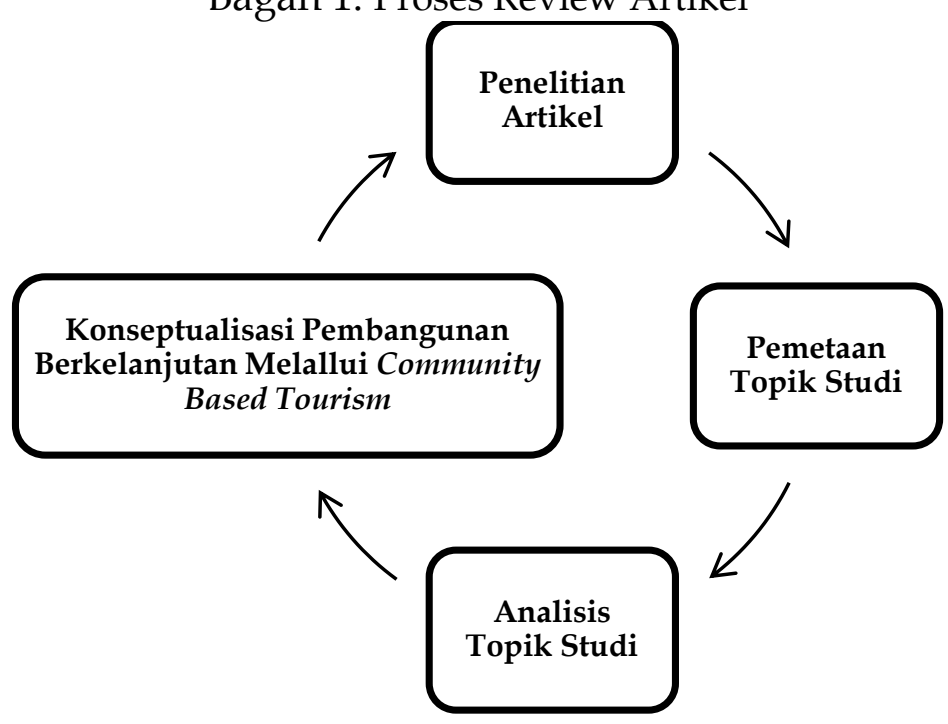

Artikel ini dicari melalui beberapa tahap. Tahap pertama identifikasi artikel, artikel tersebut diambil dari publikasi berbagai penerbit dengan menggunakan database SCOPUS. Langkah selanjutnya, peneliti memasukkan kata kunci "Sustainable Development and Community Based Tourism" dan diberikan pembatasan tahun terbit hanya hanya untuk dua tahun terakhir atau sama dengan mulai tahun 2019 hingga tahun 2021. Pencarian tersebut menghasilkan tampilan sebanyak 266 artikel yang relevan dengan topik penelitian ini. Angka tersebut didapat dari jumlah file berbentuk (ris) yang di export ke dalam software mendeley.

Setelah di dapatkan 266 artikel yang relevan, kemudian dilakukan systematic literature review. Systematic literature review dibantu dengan software analisis VOSviewer. Penggunaan software VOSviewer bertujuan untuk membantu merumuskan klasterisasi konsep (Nafi'ah et al, 2021). Systematic Literature Review juga dilakukan dengan cara memahami isi dari sebuah paper dengan mencari dan menggali lebih dalam poin penting yang terdapat dalam paper tersebut dan apa yang diargumentasikan oleh penulis paper tersebut.

\section{HASIL DAN PEMBAHASAN}

Pada bagian ini, dilakukan analisis bibliometrik dengan membuat visualisasi network, dan density menggunakan VOSviewer untuk mengetahui jaringan bibliometrik yang ada diantara artikel-artikel dari metadata yang telah diunduh. Jaringan bibliometrik ini terdiri dari node dan edge. Node dipresentasikan dengan lingkaran yang isinya berupa publikasi; jurnal; peneliti; dan kata kunci. Sedangkan edge mengindikasikan hubungan antara pasangan node. Namun Edge ini tidak hanya mengindikasikan adanya hubungan antara dua node, tetapi juga mengindikasikan kekuatan hubungan tersebut yang direpresentasikan dengan jarak, semakin dekat jarak antara node satu dengan 
node yang lain maka semakin tinggi hubungan diantara node tersebut.

\subsection{Keterkaitan dan Pengelompokkan Tema dalam Hubungan Antara Pembangunan}

Berkelanjutan dengan Community Based Tourism

Berikut ini hasil visualisasi network berdasarkan keterkaitan dan pengelompokkan katakunci.

Gambar 1. Visualisasi Network Pemetaan dan Pengklasteran dari 168 artikel yang telah terindentifikasi

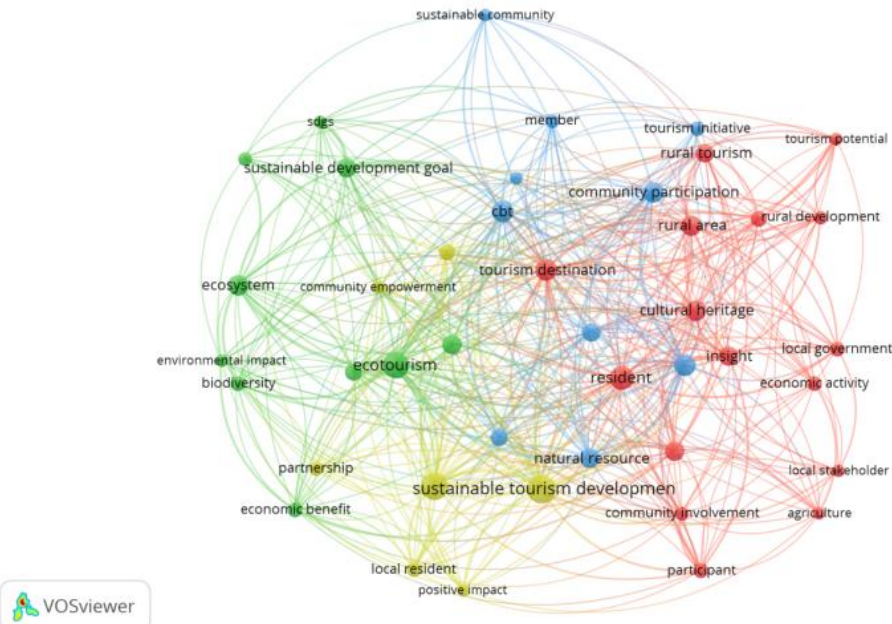

Pada visualisasi network yang ditampilkan pada gambar 1, setiap lingkaran mewakili sebuah kata kunci yang diambil dari judul dan abstrak artikel. Ukuran besar kecil sebuah lingkaran mengindikasikan jumlah publikasi yang memiliki relasi dengan kata kunci tersebut, baik di dalam jurnal maupun pada abstrak jurnal, semakin besar ukuran lingkaran maka semakin besar pula jumlah artikel yang memiliki relevansi dengan kata kunci tersebut.

Dari hasil analisis ditemukan bahwa terdapat 168 artikel dari 266 artikel yang teridentifikasi yang dikelompokkan menjadi 4 cluster. Masing-masing cluster memiliki warna yang berbeda-beda yang digunakan untuk melihat daftar konsep yang menonjol atau dominan dari setiap cluster. Tujuannya adalah untuk mengidentifikasi sebanyak mungkin tema yang sering dibahas dalam penelitian sebelumnya dan memungkinkan untuk digunakan di penelitian masa depan. Berdasarkan gambar 1 dapat dilihat bahwa cluster 1 berwarna merah yang berada di sebelah kanan, mencakup kata kunci rural tourism; tourism potential; rural area; rural development; tourism destination; cultural heritage; resident, insight, local government; economic activity; local stakeholder; community involvement; agriculture. Cluster 2 berwarna hijau yang berada di sebelah kiri, mencakup kata kunci sustainable development, sdgs; ecosystem; ecotourism; environmental impact, biodiversity; economic benefit. Cluster 3 berwarna biru yang berada di tengah atas, mencakup kata kunci sustainable community; member, tourism inisiative; community participation; cbt; natural resource. Cluster terakhir yaitu cluster 4 berwarna kuning yang berada di tengah bawah, mecakup kata kunci community empowerment; partnership; local resident, positive impact, sustainable development tourism. Kata kunci yang ada di dalam masing-masing cluster secara rinci dapat dilihat pada tabel 1 .

Tabel 1. Pengelompokkan Tema dalam Hubungan Antara Pembangunan Berkelanjutan dengan Community Based Tourism

\begin{tabular}{llc}
\hline Cluster & Nama Konsep & Total \\
\hline Cluster 1 & $\begin{array}{l}\text { Agriculture, community involvement, cultural heritage, economic activity, insight, } \\
\text { local government, local stakeholder, participant, resident, rural area, rural }\end{array}$ & 16 \\
\hline
\end{tabular}




\begin{tabular}{llc}
\hline Cluster & Nama Konsep & Total \\
\hline Cluster 2 & $\begin{array}{l}\text { community, rural development, rural tourism, tourism destination, tourism } \\
\text { potential, tourist potential } \\
\text { Biodiversity, economic benefit, ecosystem, ecotourism, environmental impact, local } \\
\text { person, sdgs, sustainable development, sustainable management, tourism sector }\end{array}$ & 10 \\
Cluster 3 & $\begin{array}{l}\text { CBT, community development, community member, community participation, } \\
\text { member, natural resource, participation, sustainable community, sustainable } \\
\text { Clivelihood, tourism initiative } \\
\text { Community empowerment, empowerment, local resident, partnership, positive } \\
\text { impact, relationship, sustainable tourism development }\end{array}$ & 70 \\
\hline
\end{tabular}

Pada cluster 1 berkaitan dengan strategi dan aspek-aspek yang dibutuhkan dalam pembangunan berkelanjutan melalui community based tourism, maka artikel yang relevan yaitu seperti artikel yang ditulis oleh Arintoko et al. (2020) yang berjudul "Community-based tourism village development strategies: A case of Borobudur tourism village area, Indonesia" yang dimana dalam artikel ini dijelaskan bahwa konsep pembangunan desa berbasis community based tourism menjadi penting dalam bagian strategi pembangunan pariwisata berkelanjutan. Hasil penelitian Arintoko et al. (2020) menunjukkan bahwa strategi pengembangan desa wisata berbasis community based tourism dapat dilakukan dengan lebih menekankan pada strategi yang bertumpu pada kekuatan dan peluang. Dalam penelitiannya Arintoko et al. (2020) menggunakan strategi SWOT, penerapan keempat strategi tersebut digunakan karena akan saling melengkapi guna mencapai tujuan pengembangan kawasan strategis pariwisarta melalui desa wisata berbasis community based tourism.

Selain itu, artikel yang relevan dengan cluster 1 yaitu artikel yang ditulis oleh Mahendrawati (2020) yang berjudul "Policy on protection of cultural heritage through communal copyright in supporting sustainable tourism" yang menjelaskan bahwa dalam memperhatikan keterpaduan pariwisata tentunya melibatkan multidisiplin di dalamnya sehingga upaya pengembangan pariwisata membutuhkan upaya terintegrasi dari berbagai pihak serta multidisplin. Perlu disadari bahwa daya tarik pariwisata di Indonesia dapat terdiri dari segala sesuatu yang memiliki keunikan, keindahan, dan nilai berupa keanekaragaman hayati, budaya, dan buatan manusia. Secara nyata dapat dilihat bahwa warisan budaya merupakan salah satu aset berharga yang dimiliki oleh Indonesia dalam mendukung perkembangan pawisata.

Pada cluster 2 kata kunci yang dominan yaitu ecotourism, maka artikel yang relevan yaitu artikel yang ditulis oleh Elbarmelgy et al. (2019) yang berjudul "Community-based ecotourism planning in Egypt, a case study: Evaluation of dahshur initiative". Dalam artikel tersebut dijelaskan bahwa pariwisata telah menjadi salah satu pendapatan nasional, maka dari itu pemerintah mencari strategi dan rencana baru untuk secara aktif mendukung partisipasi masyarakat lokal, strategi tersebut melalui ekowisata berbasis masyarakat. Ekowisata berbasis masyarakat telah menjadi pendekatan terbaru dalam proses perencanaan pembangunan pariwisata, muncul untuk mendukung keterlibatan masyarakat, meningkatkan taraf hidup masyarakat, dan melindungi sumber daya alam (Elbarmelgy et al., 2019).

Adapun artikel lain yang berkaitan dengan kata kunci ecotourism yang ada di cluster 2 yaitu artikel yang ditulis oleh Harianto et al. (2020) yang berjudul "Development strategy for ecotourism 
management based on feasibility analysis of tourist attraction objects and perception of visitors and local communities". Hasil penelitian Harianto et al. (2020) menunjukkan bahwa secara keseluruhan kondisi pengelolaan dan potensi objek wisata mendapatkan peringkat kelayakan untuk dikembangkan, persepsi tersebut diperkuat dengan adanya atraksi yang ditawarkan dan layanan pengelola serta adanya keinginan masyarakat untuk selalu dilibatkan dalam proses pembangunan.

Pada cluster 3 kata kunci yang dominan yaitu community participation, maka salah satu artikel yang relavan yaitu artikel yang ditulis oleh Setokoe \& Ramukumba (2019) yang berjudul "The importance community participation in tourism development to ensure sustainable rural development" yang menyatakan bahwa pentingnya masyarakat dalam pembangunan pariwisata dengan tujuan untuk memastikan pembangunan pedesaan yang. Hasil penelitian Setokoe \& Ramukumba (2019) menunjukkan bahwa masyarakat memandang partisipasi mereka sebagai hal terpenting dalam prakarsa pembangunan yang dilakukan di daerah tersebut, oleh karena itu partispasi masyarakat harus memungkinkan peningkatan kapasitas dan pemberdayaan bagi anggota masyarakat untuk berpartisipasi secara bermakna dalam pembangunan berkelanjutan. Selain itu, kepemimpinan masyarakat (pemerintah, tradisional, dan bisnis) harus mendorong dan memungkinkan masyarakat lokal untuk berpartisipasi dalam kegiatan pariwisata dan pembangunan lainnya untuk memastikan pembangunan endogen dan meminimalkan kendali eksternal atas pembangunan di daerah tersebut.

Selain itu, artikel yang sesuai dengan kata kunci yang ada di cluster 3 yaitu artikel yang ditulis oleh Dolezal \& Novelli (2020) yang berjudul "Power in community-based tourism: empowerment and partnership in Bali" yang dimana dalam penelitian ini memberikan pemahaman baru tentang pemberdayaan dalam konsep community based tourism, terutama sejauh mana kemitraan dan kolaborasi menciptakan ruang untuk pemberdayaan warga dan inklusi yang lebih besar untuk pengembangan CBT berkelanjutan sejalan dengan 17 SDGs 2030.

Pada cluster 4 kata kunci yang dominan yaitu sustainable tourism development, maka salah satu artikel yang relevan yaitu seperti artikel yang ditulis oleh Khalid et al. (2019) yang berjudul "Community empowerment and sustainable tourism development: The mediating role of community support for tourism". Hasil penelitian Khalid et al. (2019) menunjukkan bahwa adanya hubungan yang signifikan antara pemberdayaan masyarakat dan inisiatif sustainable development goals, dan dukungan masyarakat untuk pariwisata terbukti secara parsial memedikasi hubungan antara kediua variabel tersebut. Pemberdayaan masyarakat yang tinggi memungkinkan masyarakat untuk membangun pembangunan pariwisata berkelanjutan yang sukses melalui dukungan masyarakat lokal terhadap pariwisata, selain itu adanya dukungan anggota masyarakat terhadap pariwisata memiliki fungsi penting yang menjembatani hubungan dari pemberdayaan masyarakat untuk mempertahankan pariwisata di daerah setempat (Khalid et al., 2019).

Selain itu artikel yang sesuai dengan kata kunci cluster 4 yaitu artikel yang ditulis oleh Wardana et al. (2019) yang berjudul "Cultural tourism and ecotourism empowerment in the sustainable tourism development and destination competitiveness enhancement yang menunjukkan bahwa pariwsiata budaya dan ekowisata berpengaruh positif dan signifikan terhadap upaya pengembangan pariwisata berkelanjutan, selain itu adanya dukungan masyarakat lokal mampu memoderasi hubungan antara 
wisata budaya dan ekowisata dengan pembangunan pariwisata berkelanjutan. Hasil penelitian Wardana et al. (2019) memberikan indikasi bahwa pelestarian budaya, lingkungan alam, lingkungan sosial, dan peran serta masyarakat lokal merupakan unsur utama dalam model pembangunan pariwisata berkelanjutan dan peningkatan daya saing destinasi.

\subsection{Tema Dominan dalam Hubungan Pembangunan Berkelanjutan dengan Community Baaed Tourism}

Setelah melalukan visualisasi network, selanjutnya dilakukan visualisasi density. Dari hasil visualisai density (lihat gambar 2) menunjukkan bahwa masingmasing kata kunci memiliki distignasi dari sisi ketebalan warna, yang dimana hal tersebut menunjukkan bahwa kata kunci dengan warna yang cenderung tebal atau padat merupakan kata kunci dominan yang dibahas oleh penelitian terdahulu yang berkaitan dengan topik bahasan penelitian ini.

Gambar 2. Visualisasi Density Pemetaan dan Pengklasteran berdasarkan kata kunci dominan

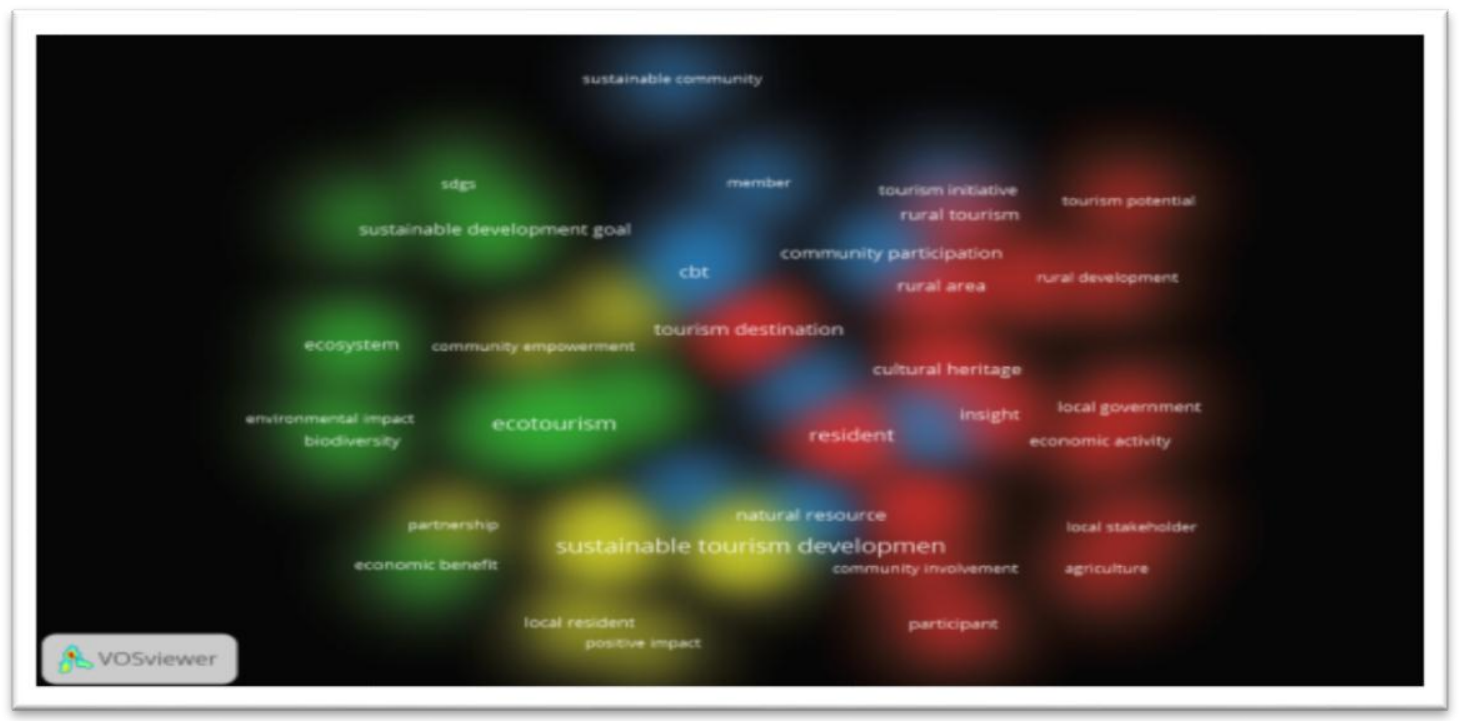

Tema dominan yang dimaksud yaitu tema yang memiliki keterkaitan antara pokok pembahasan dengan tema yang diambil, sebelum melakukan pengkajian perlu adanya sebuah pemahaman terkait tema yang diambil dan arah dari topik-topik yang terkait pada pokok pembahasan. Melalui pengelolaan tema ini, maka dapat dilihat seperti gambar 2 yang ada di atas.

Dari gambar 2 terlihat jelas bahwa kata kunci yang lebih dominan yaitu (1) Tourism Destination; (2) Ecotourism; (3) cbt; (4) Sustainable Toursim Development. Keempat kata kunci yang dominan tersebut memang seringkali digunakan oleh peneliti-peneliti terdahulu karena keempat kata kunci tersebut sangat erat kaitannya dengan topik pembahasan sustainable developemnent dan community based tourism. Kata kunci seperti tourism destination dan ecotourism merupakan kata kunci yang berkaitan dengan aspek yang digunakan untuk menerapkan community based tourism, karena dalam menerapkan CBT ini sangat diperlukan adanya tourism destination dan ecotourism. Sedangkan kata kunci CBT ini berkaitan dengan salah satu strategi dalam mewujudkan pembangunan berkelanjutan (sustainable development). CBT ini dinilai sebagai salah satu cara efektif dalam mewujudkan (sustainable development). Untuk kata kunci yang lain 
merupakan kata kunci pendukung atau kata kunci yang memiliki tujuan pembahasan yang sejalan sehingga mendukung kata kunci dominan yang ada, begitu juga dengan sebaliknya.

\subsection{Author Dominan dalam Studi Hubungan Pembangunan Berkelanjutan dengan Community Based Tourism}

Setelah melakukan visualisasi terkait kata kunci dominan, selanjutnya dilakukan visualisasi terkait dengan author dominan dalam riset suistainable development and community based tourism.

Gambar 3. Visualisasi Network author terkait dengan penelitian terdahulu

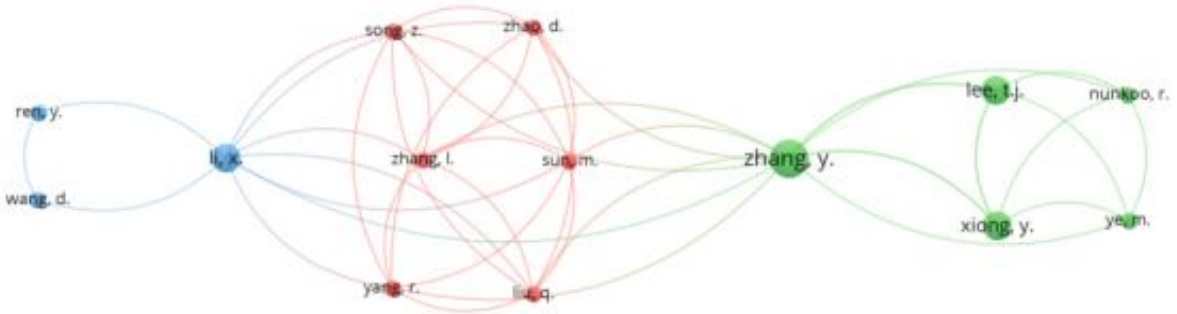

Identifikasi dalam gambar 3 menunjukkan beberapa author yang telah melakukan penelitian terdahulu dengan topik bahasan yang relevan sesuai dengan riset peneliti yaitu tentang sustainable development and community based tourism. Dari hasil visualisasi network pada gambar 3 tersebut dapat dilihat bahwa terdapat 3 cluster yang terdiri dari 14 item author. Cluster 1 berwarna merah yang berada di tengah, cluster 2 berwarna hijau yang berada di sebalah kanan, dan cluster 3 berwarna biru yang berada di sebelah kiri. Author yang ada di dalam masing-masing cluster secara rinci dapat dilihat pada tabel 2.

Tabel 2. Pengklasteran Author

\begin{tabular}{llc} 
Cluster & Nama Author & Total \\
\hline Cluster 1 & Liu, q; song, z; sun, m; yang, r; zhang, l; zhao, d & 6 \\
Cluster 2 & Lee, t.j; nunkoo, r; xiong, y; ye, m; zhang, y & 5 \\
Cluster 3 & Li, x; ren, y; wang, d & 3
\end{tabular}

Pada cluster 1, dapat dilihat bahwa tidak ada author yang paling dominan dalam topik bahasan sustainable development dan community based tourism, karena secara menyuluruh author yang berada di cluster 1 memiliki keterkaitan dan kedudukan yang sama atau dominan dalam melakukan penulisan artikel yang berkaitan dengan sustainble development and community based tourism.

Pada cluster 2, dapat dilihat bahwa author yang paling dominan adalah Zhang, $\mathrm{y}$. Zhang, $y$, merupakan penulis artikel yang berjudul "Sociocultural Sustainability and the Formation of Social Capital from Community-based Tourism". Hasil penelitian Zhang et al. (2021) mengungkapkan bahwa sifat multidimensi dari dampak sosial pariwisata yang dirasakan pada modal sosial dalam komunitas pariwisata Tiongkok dan berkontrubusi pada pemahaman yang lebih baik tentang bagaimana penduduk memandang modal sosial yang terkait dengan community based tourism sebagai bagian dari pembangunan berkelanjutan.

Selain itu, Zhang, y juga merupakan seorang penulis artikel yang berjudul 
"Residents' perception of the influence of luxury chain hotels on ethnic tourism communities. Hasil panelitian Zhang et al. (2019) menyoroti masalah penting dalam dampak ekonomi; sosial budaya; dan lingkungan, termasuk pembagian keuntungan ekonomi yang tidak adil, persepsi bermata dua tentang hotel dan mata pencaharian lokal, potensi kekhawatiran tentang keyakinan agama dan peningkatan status perempuan, optimisisme yang berlebihan tentang kemungkinan pengaruh negatif terhadap lingkungan lokal; kehidupan sehari-hari; dan tradisional. Pada penelitiannya Zhang et al. (2019) bertujuan untuk mengidentifikasi dampak yang dirasakan oleh masyarakat lokal mengenai pengembangan hotel mewah di Cina dan bagaimana masyarakat lokal mengomentari dampak tersebut ketika mencoba menggunakan hotel mewah secara efektif dalam strategi pembangunan berkelanjutan.

Pada cluster 3, dapat dilihat bahwa author yang paling dominan adalah $\mathrm{Li}, \mathrm{x}$. $\mathrm{Li}, \mathrm{x}$, merupakan salah satu penulis artikel berjudul "Impacts of human disturbances on riparian herbaceous communities in a Chinese karst river". Dalam penelitiannya Li et al. (2019) membahas tentang pentingnya untuk memahami pengaruh aktivitas manusia pada komunitas tumbuhan untuk pengembangan pariwisata yang rasional dan program perlindungan ekologi. Li et al. (2019) juga menyarankan agar terdapat peraturan tentang bendungan dan waduk yang sesuai, larangan perusakan tanah, dan program penelitian jangka panjang untuk perlindungan ekosistem agar dapat membantu dalam meningkatkan pemantauan pengaruh manusia dan pengelolaan berkelanjutan di zona riparian sungai wisata. Selain itu Li, x juga merupakan penulis artikel yang berjudul "Comprehensive partitions and different strategies based on ecological security and economic development in Guizhou Province, China". Dalam penelitiannya $\mathrm{Li}$ et al. (2020) membahas tentang degradasi ekologi global dan pertumbuhan ekonomi yang cepat telah meningkatkan fokus pada hubungan berkelanjutan antara keamanan ekologi dan pembangunan ekonomi.

Setelah melalukan visualisasi network, selanjutnya dilakukan visualisasi density. Dari hasil visualisai density (lihat gambar 4) menunjukkan bahwa masingmasing author memiliki distignasi dari sisi ketebalan warna, yang dimana hal tersebut menunjukkan bahwa author dengan warna yang cenderung tebal atau padat merupakan author dominan dalam penelitian terdahulu yang berkaitan dengan topik bahasan penelitian ini.

Gambar 4. Visualisasi Density Pemetaan dan Pengklasteran berdasarkan author dominan

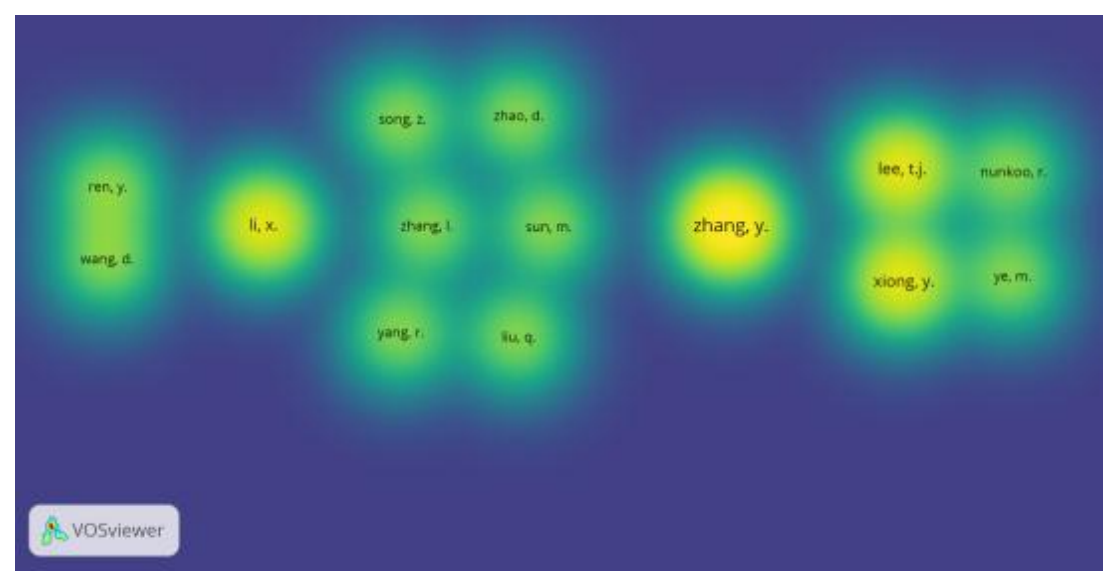


Berdasarkan data visualisasi density pada gambar 4, dapat dilihat bahwa author paling dominan yaitu pertama Zhang, y, kedua Li, x, ketiga Xiong, y, Lee, t.j. Dari keempat author tersebut mereka saling berkaitan satu dengan yang lainnya dalam penulisan artikel. Zhang, y dalam penulisan artikel sering bekerjasama dengan Li, x, Xiong, y, dan Lee, t.j. Hal tersebut dapat dibuktikan dalam penulisam artikel yang berjudul "Sociocultural Sustainability and the Formation of Social Capital from Communitybased Tourism", Zhang, y, Xiong, y, Lee, t.j saling bekerjasama dalam penulis artikel tersebut. Selain itu, dalam artikel yang berjudul "Comprehensive partitions and different strategies based on ecological security and economic development in Guizhou Province, China", Zhang, y, dan Li, x, saling bekerjasama dalam penulis artikel tersebut. Dan yang terakhir, dalam artikel yang berjudul "Residents' perception of the influence of luxury chain hotels on ethnic tourism communities", Zhang, y, Lee t.j, Xiong, $y$, juga bekerjasama dalam penulisan artikel tersebut.

Dari beberapa pemaparan poin-poin diatas, Community Based Tourism dinilai sebagai strategi yang sangat efektif untuk mrwujudkan pembangunan berkelanjutan, karena CBT berfokus pada masyarakat lokal yang dimana masyarakat lokal berperan aktif sebagai pemilik sumber daya sekaligus aktor utama dalam pengembangan sumber daya alam yang dimiliki. Jadi di dalam konsep Community Based Tourism ini, masyarakat diberdayakan untuk mengembangan keterampilan, budaya, serta potensi alam yang mereka miliki tanpa merusaknya sedikitpun, karena salah satu indikator keberhasilan pembangunan berkelanjutan adalah pelestarian lingkungan. Maka dari itu peneliti tertarik membahas topik ini karena CBT merupakan salah satu pendekatan pariwisata yang dianggap dapat mencapai kemajuan Sustainable Development Goals pertama yaitu tanpa kemiskinan dan Sustainable Development Goals ke sebelas yaitu kota dan komunikasi berkelanjutan yang dimana SDG's tersebut harus tercapai di tahun 2030.

\section{PENUTUP}

Salah satu faktor penentu bahwa pariwisata dapat berdampak positif pada masyarakat lokal yaitu penerapan konsep pengembangan pariwisata yang sesuai dengan potensi alam yang dimiliki, community based tourism dinilai salah satu model pengembangan pariwisata yang cocok dengan pembangunan pariwisata lokal karena community based tourism berfokus pada sumber daya, pemberdayaan masyarakat dan manfaat lokal. Pendekatan community based tourism merupakan salah satu prasyarat untuk pengembangan pariwisata berkelanjutan dan Community Based Tourism merupakan salah satu pendekatan terpenting dalam mewujudkan pembangunan berkelanjutan. Community Based Tourism didorong sebagai salah satu strategi pengentasan kemiskinan serta dapat meningkatkan keberlanjutan daerah dan masyarakat yang terpinggirkan. Community Based Tourism dinilai sebagai strategi yang sangat efektif untuk mewujudkan pembangunan berkelanjutan, karena CBT berfokus pada masyarakat lokal yang dimana masyarakat lokal berperan aktif sebagai pemilik sumber daya sekaligus aktor utama dalam pengembangan sumber daya alam yang dimiliki. Jadi di dalam konsep Community Based Tourism ini, masyarakat diberdayakan untuk mengembangan keterampilan, budaya, serta potensi alam yang mereka miliki tanpa merusaknya sedikitpun, karena salah satu indikator keberhasilan pembangunan berkelanjutan adalah pelestarian lingkungan. Dalam 
penerapannya, community based tourism ini diperlukan adanya partipasi aktif dari masyarakart, masyarakat dapat bertindak sebagai agen perubahan untuk mewujudkan tujuan ekowisata dan pembangunan berkelanjutan. Jadi dapat disimpulkan bahwa hubungan antara pembangunan berkelanjutan dengan community based tourism sangat erat kaitannya karena CBT dapat digunakan sebagai salah satu strategi dalam mewujudkan pembangunan berkelanjutan.

Keterbatasan dalam penelitian ini yaitu peneliti hanya mengkaji tentang hubungan antara pembangunan berkelanjutan dengan community based tourism dan belum membahas hubungan pembangunan berkelanjutan dengan indikator-indikator lain seperti ekologis; ekonomi; sosial budaya; politik; dan keberlanjutan pertahanan dan keamanan. Selain itu dalam penelitian ini, peneliti hanya menggunakan artikel dalam jumlah terbatas yakni 266 artikel sehingga hasilnya belum dapat digeneralisasikan pada kelompok pembahasan yang lebih luas.

Saran untuk peneliti selanjutnya yaitu peneliti yang tertarik untuk meneliti pembangunan berkelanjutan, agar mengkaji hubungan pembangunan berkelanjutan dengan indikator-indikator lain seperti ekologis; ekonomi; sosial budaya; politik; dan keberlanjutan pertahanan dan keamanan. Serta peneliti selanjutnya disarankan untuk menggunakan artikel yang lebih banyak agar hasilnya dapat digeneralisir dalam pembahasan yang lebih luas.

\section{DAFTAR PUSTAKA}

Abuhay, T., Abiew, D., \& Leulseged, T. (2019). Challenges and opportunities of the tourism industry in Amhara Regional State: The World Heritage sites in focus. African Journal of Hospitality, Tourism and Leisure, 8(5). https://www.scopus.com/inward/r ecord.uri?eid $=2$-s2.0-

85074404760\&partnerID $=40 \& \mathrm{md} 5=\mathrm{d}$ d92be9c1090ac5315c8467a75f56699

Arintoko, A., Ahmad, A. A., Gunawan, D. S., \& Supadi, S. (2020). Communitybased tourism village development strategies: A case of Borobudur tourism village area, Indonesia. Geojournal of Tourism and Geosites, 29(2), 398-413.

https:// doi.org/10.30892/gtg.29202477

Chan, C.-S., Nozu, K., \& Zhou, Q. (2021). Building destination resilience in the tourism disaster management process from the past experiences: The case of the 2018 Hokkaido Eastern Iburi earthquake in Japan. Tourism Recreation Research.

https:// doi.org/10.1080/02508281.20 21.1881707

Cornelisse, M. (2020). Peru case study: power relations in community-based tourism. Journal of Tourism and Cultural Change, 18(4), 437-454. https:// doi.org/10.1080/14766825.20 19.1640707

D'Souza, C., Taghian, M., Marjoribanks, T., Sullivan-Mort, G., Manirujjaman, M. D., \& Singaraju, S. (2019). Sustainability for ecotourism: work identity and role of community capacity building. Tourism Recreation Research, 44(4), 533-549. https:// doi.org/10.1080/02508281.20 19.1654727

Dolezal, C., \& Novelli, M. (2020). Power in community-based tourism: empowerment and partnership in Bali. Journal of Sustainable Tourism. https:// doi.org/10.1080/09669582.20 20.1838527

Elbarmelgy, M. M., Gammaz, S. A., \& Hussien, M. S. (2019). Communitybased ecotourism planning in Egypt, 
a case study: Evaluation of dahshur initiative. Journal of Engineering and Applied Science, 66(5), 539-561. https://www.scopus.com/inward/r ecord.uri?eid=2-s2.0-

$85073605476 \&$ partnerID $=40 \& \mathrm{md} 5=\mathrm{e} 0$ ae72e78ecc07bd94acb5079f87310a

Fan, H. (2020). Research on Sustainable Development of Coastal Rural Ecotourism Based on Tourism Perception. Journal of Coastal Research, 115(sp1), 53-55. https://doi.org/10.2112/JCR-SI115016

Feyers, S., Stein, T., \& Klizentyte, K. (2020). Bridging worlds: Utilizing a multi-stakeholder framework to create extension-tourism partnerships. Sustainability (Switzerland), 12(1), 1-23. https://doi.org/10.3390/SU12010080 Giampiccoli, A., \& Mtapuri, O. (2020).

Towards a coalescence of the community-based tourism and "albergo difusso" tourism models for sustainable local economic development. African Journal of Hospitality, Tourism and Leisure, 9(1), 1-20.

https://www.scopus.com/inward/r ecord.uri?eid=2-s2.0-

85078242798\& partnerID $=40 \& \mathrm{md} 5=6 \mathrm{e}$ 263c135f6472507348ef5d40e051e7

Han, H., Eom, T., Al-Ansi, A., Ryu, H. B., \& Kim, W. (2019). Community-based tourism as a sustainable direction in destination development: An empirical examination of visitor behaviors. Sustainability (Switzerland), 11(10). https://doi.org/10.3390/su11102864

Harianto, S. P., Masruri, N. W., Winarno, G. D., Tsani, M. K., \& Santoso, P. J. T. (2020). Development strategy for ecotourism management based on feasibility analysis of tourist attraction objects and perception of visitors and local communities. Biodiversitas, 21(2), 689-698. https://doi.org/10.13057/biodiv/d2 10235

Hlengwa, D. C., \& Maruta, A. T. (2019). Community based tourism ventures apt for communities around the save valley conservancy in Zimbabwe. African Journal of Hospitality, Tourism and Leisure, 8(2).

Ibrahim, M. S. N., Halim, S. A., \& Ishak, M. Y. (2019). The impacts of tourism development on community wellbeing in Langkawi: The case of Kampung Padang Puteh, Mukim Kedawang. Journal of Marine and Island Cultures, 8(2), 61-88. https:// doi.org/10.21463/jmic.2019.0 8.2 .06

Jia, Z., Gao, M., Xu, S., Lyu, Y., Feng, J., Zhou, Z., Yu, T., \& Wu, W. (2020). Sociocultural vitality versus regulation policy and tourism development in preservation of traditional rural landscape: a case from Guizhou, China. International Journal of Sustainable Development and World Ecology, 1-14. https:// doi.org/10.1080/13504509.20 20.1788661

Juma, L. O., \& Khademi-Vidra, A. (2019). Community-based tourism and sustainable development of rural regions in Kenya; Perceptions of the citizenry. Sustainability (Switzerland), 11(17).

https://doi.org/10.3390/su11174733

Khalid, S., Ahmad, M. S., Ramayah, T., Hwang, J., \& Kim, I. (2019). Community empowerment and sustainable tourism development: The mediating role of community support for tourism. Sustainability (Switzerland), 11(22). https:// doi.org/10.3390/su11226248

P-JIAP: Vol. 6 (2) 2021 
Koščak, M., O'Rourke, T., \& Bilić, D. (2019). Community participation in the planning of local destination management . Informatologia, 52(43924), 125-135. https://doi.org/10.32914/I.52.3-4.1

Li, X., Ren, Y., \& Wang, D. (2019). Impacts of human disturbances on riparian herbaceous communities in a Chinese karst river. Nature Environment and Pollution Technology, 18(4), 1107-1118. https://www.scopus.com/inward/r ecord.uri?eid=2-s2.0-

85077256592\& partnerID $=40 \& m d 5=86$ 620dc44066bf0bffac81e3defbce88

Li, X., Sun, M., Yang, R., Zhang, Y., Zhang, L., Song, Z., Liu, Q., \& Zhao, D. (2020). Comprehensive partitions and different strategies based on ecological security and economic development in Guizhou Province, China. Journal of Cleaner Production, 274.

https://doi.org/10.1016/j.jclepro.202 0.122794

Mahendrawati, N. L. M. (2020). Policy on protection of cultural heritage through communal copyright in supporting sustainable tourism. Journal of Environmental Management and Tourism, 11(4), 920-924.

https://doi.org/10.14505/jemt.11.4(4 4). 16

McNaughton, M., Rao, L., \& Verma, S. (2020). Building smart communities for sustainable development:: Community tourism in Treasure Beach Jamaica. Worldwide Hospitality and Tourism Themes, 12(3), 337-352. https://doi.org/10.1108/WHATT02-2020-0008

Mohanty, P. P., Rout, H. B., \& Samal, A. (2019). Community based sustainable tourism development - A tool for fostering and promoting peace: $\mathrm{A}$ case study of Odisha, India. African
Journal of Hospitality, Tourism and Leisure, 8(1), 1-15.

https://www.scopus.com/inward/r ecord.uri?eid=2-s2.085059513183\&partnerID $=40 \& m d 5=98$ f6544819a7d020af185b4389d30848

Müllera, S., Hucka, L., \& Markovab, J. (2020). Sustainable community-based tourism in cambodia and tourists' willingness to pay. Austrian Journal of South-East Asian Studies, 13(1), 81-101. https:// doi.org/10.14764/10.ASEAS0030

Muresan, I. C., Harun, R., Arion, F. H., Oroian, C. F., Dumitras, D. E., Mihai, V. C., Ilea, M., Chiciudean, D. I., Gliga, I. D., \& Chiciudean, G. O. (2019). Residents' perception of destination quality: Key factors for sustainable rural development. Sustainability (Switzerland), 11(9). https:// doi.org/10.3390/su11092594

Nafi'ah, B. A., Roziqin, A., Suhermanto, D. F., \& Fajrina, A. N. (2021). The Policy Studies journal: A Bibliometric and mapping study from 20152020.

Library Philosophy and Practice, 5881, 1-18.

Nguyen, D. T. N., d'Hauteserre, A.-M., \& Serrao-Neumann, S. (2021). Intrinsic barriers to and opportunities for community empowerment in community-based tourism development in Thai Nguyen province, Vietnam. Journal of Sustainable Tourism. https:// doi.org/10.1080/09669582.20 21.1884689

Nicolaides, A. (2020). Sustainable ethical tourism (SET) and rural community involvement. African Journal of Hospitality, Tourism and Leisure, 9(1), 1-16.

https://www.scopus.com/inward/r ecord.uri?eid=2-s2.0$85078235700 \&$ partnerID $=40 \& m d 5=a b$ 
3b8c9835897650964b026728cff4e0

Nomnian, S., Trupp, A., Niyomthong, W., Tangcharoensathaporn, P., \& Charoenkongka, A. (2020). Language and community-based tourism: Use, needs, dependency, and limitations. Austrian Journal of South-East Asian Studies, 13(1), 57-79. https://doi.org/10.14764/10.ASEAS0029

Nordin, A. O. S., Ismail, F., \& Jamal, N. Y. M. (2020). Impact of tourism development on the quality of life: A case study of Perhentian Island, Malaysia. African Journal of Hospitality, Tourism and Leisure, 9(3), 22-37. https://doi.org/10.46222/ ajhtl.19770 720-2

Pasanchay, K., \& Schott, C. (2021). Community-based tourism homestays' capacity to advance the Sustainable Development Goals: A holistic sustainable livelihood perspective. Tourism Management Perspectives, 37. https://doi.org/10.1016/j.tmp.2020.1 00784

Pickel-Chevalier, S., Bendesa, I. K. G., \& Darma Putra, I. N. (2019). The integrated touristic villages: an Indonesian model of sustainable tourism? Tourism Geographies. https:/ / doi.org/10.1080/14616688.20 19.1600006

Pranee, S. (2019). A community based tourism model of OTOP Village Champion (OVC): A case study of Hat Sompan Village, Ranong Province. African Journal of Hospitality, Tourism and Leisure, 8(2). https://www.scopus.com/inward/r ecord.uri?eid=2-s2.0-

$85062964841 \&$ partnerID $=40 \& \mathrm{md} 5=\mathrm{b} 7$ b451348621448b67a3ed7beab0a990

Radianto, E., Prabawa, T. S., Therik, W. M. A., Sasongko, G., \& Ndoen, M. L.
(2019). The role of tourism in development: A dilemma between economic growth and mangrove forest degradation (a case study of regencies/cities in North Maluku Province). Jurnal Manajemen Hutan Tropika, 23(5), 185-198. https://doi.org/10.7226/jtfm.25.3.18 5

Raftopoulos, M. (2020). Rural

Community-Based Tourism and its Impact on Ecological Consciousness, Environmental Stewardship and Social Structures. Bulletin of Latin American Research, 39(2), 142-156. https:// doi.org/10.1111/blar.12749

Rami, A. M., Simin, H., Abdullah, R., \& Ibrahim, A. (2019). Community leader in enhancing rural economic growth in state of Terengganu, Malaysia. International Journal of Recent Technology and Engineering, 8(2 Special Issue 11), 680-684.

https:/ / doi.org/10.35940/ijrte.B1108. $0982 S 1119$

Rosalina, P. D., Dupre, K., \& Wang, Y. (2021). Rural tourism: A systematic literature review on definitions and challenges. Journal of Hospitality and Tourism Management, 47, 134-149. https://doi.org/10.1016/j.jhtm.2021. 03.001

Roziqin, A., \& Syarafina, Z. (2021). Tourism village development study: Lesson learned from Flory Village, Sleman Regency, Yogyakarta. Masyarakat, Kebudayaan Dan Politik, 34(2), 173.

https:// doi.org/10.20473/mkp.v34i2 2021.173-183

Saarinen, J., Moswete, N., Atlhopheng, J. R., \& Hambira, W. L. (2020). Changing socio-ecologies of Kalahari: Local perceptions towards environmental change and tourism in Kgalagadi, Botswana. Development

P-JIAP: Vol. 6 (2) 2021 
Southern Africa, 37(5), 855-870.

https://doi.org/10.1080/0376835X.20 20.1809997

Santos, L. L., Cardoso, L., Araújo-Vila, N., \& Fraiz-Brea, J. A. (2020).

Sustainability perceptions in tourism and hospitality: A mixed-method bibliometric approach. Sustainability (Switzerland), 12(21), 1-18. https://doi.org/10.3390/su12218852

Sène-Harper, A., \& Séye, M. (2019).

Community-based Tourism Around

National Parks in Senegal: The Implications of Colonial Legacies in Current Management Policies.

Tourism Planning and Development, 16(2), 217-234.

https://doi.org/10.1080/21568316.20

18.1563804

Setokoe, T. J., \& Ramukumba, T. (2019).

The importance community participation in tourism development to ensure sustainable rural development. African Journal of Hospitality, Tourism and Leisure, 8(SpecialEdition), 1-12.

https://www.scopus.com/inward/r ecord.uri?eid=2-s2.0-

85083788992\&partnerID $=40 \& m d 5=11$ f21f5bf55714cec04a391155fc0a1e

Stone, M. T., \& Stone, L. S. (2020).

Challenges of community-based tourism in Botswana: a review of literature. Transactions of the Royal Society of South Africa, 75(2), 181-193. https://doi.org/10.1080/0035919X.20 20.1715510

Strydom, A. J., Mangope, D., \& Henama, U.S. (2019). A critique of the interface between tourism, sustainable development and sustainable tourism in communitybased tourism theory. African Journal of Hospitality, Tourism and Leisure, 8(5).

https://www.scopus.com/inward/r ecord.uri?eid=2-s2.0-
$85074409430 \&$ partnerID $=40 \& \mathrm{md} 5=\mathrm{c} 7$ 2fad5985af9017e670b64809139ba1

Wardana, I. M., Sukaatmadja, I. P. G., Yasa, N. N. K., \& Astawa, I. P. (2019). Cultural tourism and ecotourism empowerment in the sustainable tourism development and destination competitiveness enhancement. Journal of Environmental Management and Tourism, 10(4), 753-762.

https:// doi.org/10.14505/jemt.v10.4( 36). 06

Wikantiyoso, R., Cahyaningsih, D. S., Sulaksono, A. G., Widayati, S., Poerwoningsih, D., \& Triyosoputri, E. (2021). Development of Sustainable Community-Based Tourism in Kampong Grangsil, Jambangan Village, Dampit District, Malang Regency. International Review for Spatial Planning and Sustainable Development, 9(1), 64-77. https:// doi.org/10.14246/IRSPSD.9.1 -64

Wondirad, A., \& Ewnetu, B. (2019). Community participation in tourism development as a tool to foster sustainable land and resource use practices in a national park milieu. Land Use Policy, 88.

https:// doi.org/10.1016/j.landusepol .2019 .104155

Yergeau, M.-E. (2020). Tourism and local welfare: A multilevel analysis in Nepal's protected areas. World Development, 127. https:// doi.org/10.1016/j.worlddev. 2019.104744

Zhang, Y., Lee, T. J., \& Xiong, Y. (2019). Residents' perception of the influence of luxury chain hotels on ethnic tourism communities. Journal of Tourism and Cultural Change, 17(4), 432-448.

https:// doi.org/10.1080/14766825.20 19.1591700 
Zhang, Y., Xiong, Y., Lee, T. J., Ye, M., \& Nunkoo, R. (2021). Sociocultural Sustainability and the Formation of Social Capital from Community- based Tourism. Journal of Travel

Research, 60(3), 656-669.

https:/ / doi.org/10.1177/0047287520 933673 